\title{
A Leech in the nasopharynx of an infant: A Case Report
}

\author{
Saeid Sadeghian ${ }^{1 *}$, Nasrin Sharafi ${ }^{2}$ and Siavash Sadeghian ${ }^{3}$ \\ ${ }^{1}$ Department of Paediatric Neurology, Golestan Medical, Educational, and Research Centre, Ahvaz Jundishapur University of Medical Sciences, Ahvaz, Iran \\ ${ }^{2}$ Department of ENT, Zahedan University of medical Science, Zahedan, Iran \\ ${ }^{3}$ Ahvaz Jundishapur University of Medical Sciences, Ahvaz, Iran
}

\begin{abstract} infested water. Leech infestation can lead to serious problems in the aerodigestive tract.

\section{Introduction}

Leeches are the phylum Annelida parasites of the class Hirudinea. They are blood-feeding organisms that attach to host tissues and suck blood by biting through the wounded skin or aerodigestive mucosa [1]. Leeches may adhere to the pharynx or larynx by drinking infested water from lakes, swamps, wells, and springs. Swimming in contaminated water is another way for infested with leeches [2]. More frequently involved areas in patient with leech infestation are pharynx, larynx, bronchi, vagina, esophagus or rectum. Leech infestation may lead to severe anemia, hematemesis, hemoptysis, and epistaxis [2-4]. In this report, we present a 7-month-old infant with hematemesis, epistaxis and bloody feces after drinking the Well water that led to leech entry into the nasopharynx [5]. So far, there have been few reports of human infection with leeches in Iran, including two reports of leech infestation in nasopharyngeal with hemorrhage by Jafari Roohi et al. [2] and Mirzaei [6], and also leech infestation in the esophagus report by Hemati and Colleagues [7].
\end{abstract}

Introduction: Infestation with leeches can happen due to drinking from spring water or other unhealthy and non-hygienic sources of water or swimming in this

Case report: In this report, we described a 7-month-old infant presented to Abuzar Hospital of Ahvaz with hematemesis, epistaxis and bloody feces after drinking the Well water that led to leech entry into the nasopharynx. Removal was done, and the patient became symptom free.

Conclusion: Infestation with a leech can lead to variable symptoms in the aerodigestive tract like bleeding from the mouth, nose and anus and irritation at the site of its attachment. So, sometimes it is important that keep leech infestation in our mind, especially, when patients live in rural or suburbs areas.

\section{Case report}

A 7-month-old girl refer to emergency department of Abuzar hospital of Ahwaz with hematemesis, epistaxis and bloody feces. The patient without any history of previous illness was admitted to Dezful Hospital for 3 days. She hadn't fever or cough. In that center, she received 3 pack cells due to $\mathrm{Hb}=3.9 \mathrm{~g} / \mathrm{dl}$ and at the time of admission to Abuzar Hospital of Ahwaz had $\mathrm{Hb}=7.9 \mathrm{~g} / \mathrm{dl}$. She was ill and had bleeding from the mouth and nose. The patient was unable to oral feeding and in the clinical examination had tachycardia and soft belly without tenderness. At each bleeding stage, the blood from the mouth was about 1 glass. The biochemical parameters and UA were normal and the results of hematological tests were: $\mathrm{WBC}=9.6 /$ Cumm, $\mathrm{RBC}$ $=2.97 \mathrm{Mil} /$ Cumm, Hemoglobin = 7.9 g / dl, Platelets = 303 / Cumm, PTT $=26$ and Hematocrit $4 / 23 \%$. In ICU of Abuzar Hospital, the patient received 1 pack cell and 1 FFP unit. The patient's anus was pale. ENT consulting was done because of bleeding from the nose and mouth. Nasal hemorrhage was observed in nose examination, and in the pharyngeal examination observed no hemorrhage. The blood on the left side of nose was suctioned with nelaton. In the right nasal side suction, it seemed that there was an obstruction in the posterior choana area, and nelaton's head hit to a hard mass. There was no obstruction in suction again after 1 minute. The patient's throat was quickly examined to see the foreign body, possibly due to nasal suctioning, and the leech was observed. After two unsuccessful attempts to get leech, it was not seen in the third attempt. In the reexamination of the patient's nose, the leech was seen in the right side of the nose, which was quickly removed from the nose with a clamp without using lidocaine. Red leech with 4 $\mathrm{cm}$ long was removed from the nose (Figure 1). During this procedure, the patient did not have any respiratory problems. The patient revisited within 2 days frequently and her health condition was improved and then discharged.

\section{Discussion}

According to available reports, leeches can adhere to nasopharynx [8], larynx [9], eye [10], ear [11] and gastrointestinal tract [12]. The most common complaint of patients is bleeding that is accrued in the site of leech's infestation. Tabook et al., reported a 12-year-old boy with bloody spitting and coughing that had leech infestation of the nasopharynx [3]. Agin et al. reported a 5-year-old girl with pharyngeal leech infestation that presented by hemoptysis and epistaxis [12]. Ghimire et al. reported a leech infestation manifested by a unilateral nostril epistaxis [13]. Uppal et al., reported a leech infestation in nasal cavity of a 40-year-old man with symptoms such as nasal discharge, epistaxis, and headache [14].

*Correspondence to: Saeid Sadeghian, Department of Paediatric Neurology, Golestan Medical, Educational, and Research Centre, Ahvaz Jundishapur University of Medical Sciences, Ahvaz, Iran, E-mail: s.saeid92@gmail.com

Key words: leech, bleeding, nasopharynx

Received: May 29, 2020; Accepted: June 22, 2020; Published: June 26, 2020 


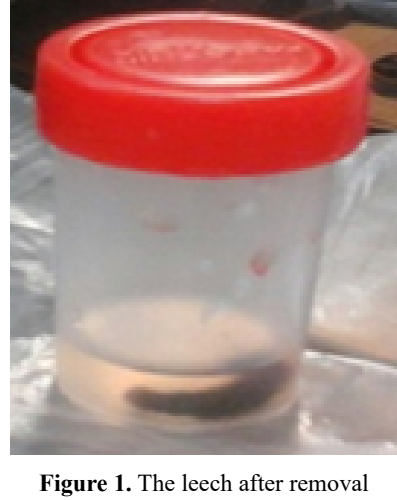

Typically, the most common site of leech attachment in the body cavities are nasopharynx and nose, but this parasite can also attach to the throat, esophagus, and other parts of the digestive tract and caused to serious complications. Al Awayasheh et al., reported a 5-yearold girl infested with a leech which caused to gastroenteritis [15]. In 2011, a rare case of rectal hemorrhage was reported in a 33-year-old patient from Turkey [5]. Ahmed and colleagues reported a 10-yearold boy with unusual bleeding from the bladder in Bangladesh [4]. In Iran, in 2010, Jafari Rohi et al., reported a 9-month-old infant with the nasopharyngeal hemorrhage due to leech infestation who lived in the suburb of Marand [2]. In 2006, Mirzai presented a 7-year-old child with leech infestation that had epistaxis and hemoptysis in a Kurdistan hospital [6]. In another case report presented by Hemmati et al., in 2002, blood vomiting due to esophageal leech infested was seen in a 3.5-year-old child living in a rural area of Ilam province [7]. In the present report, bleeding was revealed from the patient's mouth and nose. In these patients, leech must be completely removed to stop the bleeding. The use of lidocaine $4 \%$ has been reported to facilitate leech removal from the eye [16]. In the report of Jafari Rohi et al. used lidocaine to remove the leech from the nose [2]. Also, in the Tabook et al. report, used xylocaine $10 \%$ spray for local anesthetic and suppressed gag reflex after leech removal from the mouth [3]. But, as mentioned, in the present report, without using any kind of anesthetic, leech was removed from the patient's nose.

Leeches secrete Herodian as an anticoagulant that may after removing the leech, the bite bleeding more than a normal wound. The anticoagulant effect will remain a few hours after leech removal. While the leech is attached to the mucus, it can suck the blood. Large adult leeches can feed up to 10 times their body weight each time, and suck average 5-15 ml of blood [3]. In this report, bleeding was mild and quickly after leech removal, the bleeding was stopped, and the patient was discharged without any additional treatment. In other words, the leech removal was sufficient for treatment.

\section{Conclusion}

In areas where people use fountains, rivers, or aqueducts, infestation with leeches should be considered as a rare and serious cause of gastrointestinal, respiratory, and vaginal bleeding disorders. It is also suggested that residents of these areas be trained to use safe drinking-water to control and prevent the leech infestation in their areas.

\section{References}

1. Fooanant S, Puntasri W, Manorot M, Niwasabutra S (2006) A leech in the nasal cavity: Case report. Chiang Mai Med Bull 45: 27-30.

2. Jafari Rouhi AH, Vegari S, Shams Vahdati S, Porhosein D, Davarnia GH (2010) Nasopharyngeal Bleeding due to Leech Bites in a 9-month-old Infant. Indian J Pediatr 17: 573-574. [Crossref]

3. Tabook SMS, Tawab HMA (2015) A Leech in the Nasopharynx of a Child: A Case Report. IJSS Case Reports \& Reviews 1: 35-37. [Crossref]

4. Ahmmad BN, Uddin S, Rumi A (2013) Hematuria Due to Leech Bite in the Urinary Bladder: A Case Report. Bangladesh J Child Health 37: 183-185.

5. Al B, Yenen ME, Aldemir M (2013) Rectal bleeding due to leech bite: A case report Ulus Travma Acil Cerrahi Derg 17: 83-86. [Crossref]

6. Mirzaei N (2006) Epistaxis and hemoptysis due to leech bite. J Kurdistan Uni Med Sci 11: 84-87. (Persian)

7. Hemati M, Vazirizn SH, Solgee GH (2003) A case hematesis and severe anemia due to leech biting. Behbood 6: 55-59.

8. Ugur KS, Gunduz M (2011) Leech in the Nasopharynx: An Uncommon Cause of Epistaxis. Otolaryngol Head Neck Surg 145: 176-177. [Crossref]

9. Tufek A, Karaman H, Yildirim ZB, Celik F, TokgöZ O, et al. (2011) Unexpected foreign bodies in larynx: two cases report. Paediatr Anaesth 21: 467-468. [Crossref]

10. Tenkir A, Tibebu T (2010) Leech on the eye in a child. Ethiop Med J 48: 177-180. [Crossref]

11. Askari N, Eshaghian A (2012) Otorrhagia bleeding due to leech bite. Adv Biomed Res 1: 15-17. [Crossref]

12. Agin H, Ayhan FY, Gülfidan G, Cevik D, Derebasi H (2008) Severe anemia due to the pharyngeal leech Limnatis nilotica in a child. Turkiye Parazitol Derg 32: 247-248. [Crossref]

13. Ghimire A, Acharya A (2008) Unusual cause of unilateral epistaxis: Nasal leech infestation. JNMA J Nepal Med Assoc 47: 38-40. [Crossref]

14. Uppal HC, Chandel VS, Chandel L (2012) Extraction of live leech from nasal cavity: an interesting case report from a rural area hospital. Bangladesh J Otorhinolaryngol 18: $222-224$.

15. Al Awayasheh FN, Al Qa'qa' KM, Younes NS, Al Khaldi OA, Khreisat WH (2010) An unusual cause of upper gastrointestinal hemorrhage in children. JRMS 17: 30-32. [Crossref]

16. Dey R, Dey S (2010) Ocular leech infestation. Arch Iran Med 13: 440-442. [Crossref]

Copyright: $@ 2020$ Sadeghian S. This is an open-access article distributed under the terms of the Creative Commons Attribution License, which permits unrestricted use, distribution, and reproduction in any medium, provided the original author and source are credited. 